\title{
A tidewater glacier landform assemblage in Belcher Inlet, Canadian Arctic
}

\author{
C. L. BATCHELOR ${ }^{1 *}$, J. A. DOWDESWELL ${ }^{1}$, E. K. DOWDESWELL ${ }^{1}$, B. J. TODD ${ }^{2}$, M. J. SHARP ${ }^{3} \&$ T. J. BELL ${ }^{4}$ \\ ${ }^{1}$ Scott Polar Research Institute, University of Cambridge, Cambridge CB2 1ER, UK \\ ${ }^{2}$ Geological Survey of Canada, Natural Resources Canada, P.O. Box 1006, Dartmouth, Nova Scotia, CANADA B2Y $4 A 2$ \\ ${ }^{3}$ Department of Earth and Atmospheric Sciences, University of Alberta, Edmonton, Alberta, CANADA T6G 2E3 \\ ${ }^{4}$ Department of Geography, Memorial University of Newfoundland, St. John's, Newfoundland and Labrador, CANADA A1B $3 X 9$
}

*Corresponding author (e-mail: clb70@cam.ac.uk)

\begin{abstract}
Belcher Glacier, a $35 \mathrm{~km}$-long tidewater outlet glacier of the 12,000 $\mathrm{km}^{2}$ ice cap on Devon Island (Dowdeswell et al. 2004), is one of the fastest-flowing glaciers in the Canadian Arctic (Van Wychen et al. 2014) (Fig. 1). Belcher Glacier and neighbouring Fitzroy Glacier to the southeast account for about $55 \%$ of the iceberg calving loss from the Devon Ice Cap (Van Wychen et al. 2014). The terminus of Belcher Glacier remained relatively stable between the 1960s (light blue dashed line in Fig. 1a) and 2000 (Landsat 7 satellite image in Fig. 1a). In contrast, the unnamed glacier immediately to the north retreated $2 \mathrm{~km}$ during this period (Fig. 1a). Belcher Glacier and the unnamed glacier retreated around $500 \mathrm{~m}$ and $250 \mathrm{~m}$, respectively, between 2000 and 2014 (dark blue dashed line in Fig. 1a). The bed topography of Belcher Glacier, which is around $250 \mathrm{~m}$ below sea level at the present-day glacier margin (Fig. 1c) and remains below sea level in the lower $11 \mathrm{~km}$ of the glacier, suggests that its terminus region may become unstable in the event of future retreat. Seafloor mapping of Belcher Inlet beyond the termini of Belcher Glacier and the unnamed glacier (Fig. 1a), together with sub-bottom profiling, provide information about the dynamic behaviour of tidewater glaciers.
\end{abstract}

\section{Description}

The bathymetry of Belcher Inlet is dominated by a prominent break in slope that occurs around $2 \mathrm{~km}$ east of the termini of Belcher Glacier and the unnamed glacier (Fig. 1a, b). The break in slope, which is 30 $\mathrm{m}$ high and has an average gradient of $10^{\circ}$, is associated with a seaward change from a rugged to a smooth seafloor appearance on swath-bathymetric imagery (Fig. 1a). The smooth seafloor corresponds with a region of acoustically stratified reflections on subbottom profiles (Fig. 1d). At the sides of Belcher Inlet, outcrops of acoustically-impenetrable, rough terrain with a west-east trend rise up to $200 \mathrm{~m}$ above the otherwise relatively smooth seafloor (Fig. 1a, d).

An assemblage of cross-cutting landforms is preserved on the seafloor of Belcher Inlet (Figs. 1a, b, 2a). Several sets of landforms are identified: linear to curvilinear elongate ridges; asymmetric elongate ridges; transverse ridges; sediment wedges; sediment lobes; and linear to curvilinear depressions.

Linear to curvilinear streamlined elongate ridges are present on the seafloor immediately beyond the termini of Belcher Glacier and the unnamed glacier (Figs. 1a, b, 2a). Beyond the terminus of Belcher Glacier, the elongate ridges are linear and orientated in a west-east direction (Fig. 1b). The ridges are around $1.5 \mathrm{~km}$ long, $50 \mathrm{~m}$ wide and $2 \mathrm{~m}$ high, and have elongation (length-to-width) ratios of up to 30:1. Beyond the terminus of the unnamed glacier, the elongate ridges are linear to curvilinear and have west-east and northwest-southeast trends (Fig. 2a). They are up to $1.5 \mathrm{~km}$ long, $300 \mathrm{~m}$ wide and $30 \mathrm{~m}$ high (Fig. $2 b$ ), with elongation ratios of about $5: 1$. The locations of some of the elongate ridges correspond with the positions of medial moraines observed on the surface of the glaciers (Figs. 1b, 2a).

Subtle linear to curvilinear elongate ridges are also present around 8 $\mathrm{km}$ seaward of the glaciers' termini, where they overprint a sediment wedge (Fig. 1a). Here, the ridges are up to $2 \mathrm{~km}$ long, $100 \mathrm{~m}$ wide and $5 \mathrm{~m}$ high, and are orientated in a southwest-northeast direction.

Asymmetric elongate ridges, with wider and higher landward heads and narrower, more subdued seaward tails, are also present on the seafloor beyond Belcher Glacier (Fig. 1b). The asymmetric elongate ridges are curvilinear and orientated in a southwest-northeast direction (Fig. 1b). The ridges are up to $800 \mathrm{~m}$ long, $100 \mathrm{~m}$ wide and $15 \mathrm{~m}$ high, with elongation ratios of around 8:1.

The seafloor beyond the termini of Belcher Glacier and the unnamed glacier is mantled by swarms of ice-flow transverse ridges, which overprint the elongate ridges (Figs. 1b, 2a). The transverse ridges have regular spacing of 60 to $100 \mathrm{~m}$ and their crests are aligned in a north-south direction (Figs. 1b, 2a). Individual ridges can be traced horizontally from discontinuous segments of a few tens of metres to continuous segments up to $1 \mathrm{~km}$ long. The transverse ridges are 30 to $60 \mathrm{~m}$ wide, 2 to $8 \mathrm{~m}$ high, and are formed within acoustically semi-transparent sediment overlying an acoustically impenetrable reflection (Fig. 2c). The ridges are subdued or absent from overdeepened parts of the seafloor beyond the glaciers (Figs. 1b and 2a). A further swarm of transverse ridges, with dimensions similar to those identified immediately beyond the glaciers' termini, is present about $6 \mathrm{~km}$ further out on the south side of Belcher Inlet (Fig. 1a). Here, the ridge crests are orientated in a west-east direction (Fig. 1a).

Three large asymmetric sediment wedges, with shallower iceproximal sides and steeper ice-distal sides, are present on the seafloor of Belcher Inlet (Fig. 1a, 2d). The most landward wedge occurs in association with a narrowing of the deeper part of the inlet (Fig. 1a). This wedge is $3 \mathrm{~km}$ long in the former ice-flow direction, $1.8 \mathrm{~km}$ wide and $30 \mathrm{~m}$ high. The two wedges further seaward are more subdued and crescentic in shape; they are around $1.5 \mathrm{~km}$ long, $3 \mathrm{~km}$ wide and $20 \mathrm{~m}$ high (Fig. 2d).

Sediment lobes up to $500 \mathrm{~m}$ long, 120 wide and $5 \mathrm{~m}$ high are present at the base of the prominent break in slope within Belcher Inlet (Figs. 1a, b, 2a). Smaller lobes up to $100 \mathrm{~m}$ long, $80 \mathrm{~m}$ wide and $10 \mathrm{~m}$ thick are also present at the base of the steep valley wall to the south of Belcher Inlet (Fig. 1a).

Finally, several linear to curvilinear depressions are present to the south of Belcher Inlet (Fig. 1a). The depressions are up to $50 \mathrm{~m}$ wide and $2 \mathrm{~m}$ deep, and have small berms to either side.

\section{Interpretation}

The acoustically-impenetrable terrain at the sides of Belcher Inlet (Fig. 1a, d), is interpreted as ice-sculpted bedrock. The smooth basin fill to the east of the break in slope, which is acoustically stratified on sub-bottom profiles (Fig. 1d), is interpreted to have been formed largely by suspension sedimentation from turbid meltwater plumes.

The dimensions of the linear to curvilinear elongate ridges on the seafloor of Belcher Inlet (Figs. 1b, 2a) suggest that they are lineations formed subglacially by fast-flowing ice (Solheim et al. 1990; Solheim \& Elverhøi 1997). The variation in lineation curvature and orientation (Fig. 2e) is interpreted to reflect the former pattern of ice flow, which was influenced by the topography of the seafloor.

The locations of some of the linear to curvilinear elongate ridges in Belcher Inlet correspond with the positions of medial moraines on the glacier surfaces (Figs. 1b, 2a). The medial moraines are probably composed of sediment that was dumped onto the glacier surfaces from protruding outcrops of bedrock (Fig. 2a), as well as from valley walls. Some of the elongate seafloor ridges may also be at least partially formed by subglacial erosion of the bedrock outcrops as the ice slides 
past them, leading to the development of basal debris-rich layers down-glacier of the bedrock outcrops (Fig. 2a).

The dimensions, geometry and rugged seafloor appearance of the asymmetric elongate ridges in Belcher Inlet (Fig. 1b) suggest that they are rock drumlins (Benn \& Evans 2010). Rock drumlins are interpreted to form subglacially by the action of ice flowing over bedrock (e.g. Shipp \& Anderson 1997).

The swarms of ice-flow transverse ridges on the seafloor of Belcher Inlet (Figs. 1a, b, 2a, c) are interpreted as De Geer moraines. De Geer moraines are formed by sediment deposition at the terminus of a tidewater glacier during brief still-stands or readvances of the grounding zone during general retreat (Lindén \& Möller 2005). The De Geer moraines that are present landward of the break in slope in Belcher Inlet (Fig. 2e) record the locations of numerous, short-lived still-stands of the Belcher and unnamed glacier margins. The largest moraine ridges, which are generally located between shallower areas of the seafloor that probably acted as pinning points for ice-margin stabilisation, may be the product of several years of ice-front stability. The De Geer moraines which are present on the south side of Belcher Inlet (Fig. 2e) probably formed during retreat of an unnamed glacier that presently terminates on land around $3 \mathrm{~km}$ to the south of the Inlet.

The three asymmetric sediment wedges in Belcher Inlet (Figs. 1a, 2e) are interpreted as grounding-zone wedges (GZWs) formed by rapid sediment supply to the grounding-zone during a still-stand in ice retreat (Batchelor \& Dowdeswell 2015). GZWs generally form during ice-margin still-stands of decades to centuries (Alley et al. 2007; Dowdeswell et al. 2008). They are probably formed by fast-flowing glaciers that terminate in floating ice-shelves, which restrict the buildup of high-amplitude ridges at the grounding-zone (Batchelor \& Dowdeswell 2015). GZW3 in Belcher Inlet (Fig. 2e) was probably formed at this location due to the lateral constriction in topography, which provided a pinning point for grounding-zone stabilisation (Dowdeswell \& Fugelli 2012; Batchelor \& Dowdeswell 2015).

The sediment lobes on the seafloor of Belcher Inlet (Figs. 1a, 2e) are interpreted to have been formed by relatively low-magnitude subaqueous mass-wasting events. Mass-wasting on the steep break in slope (Figs. 1b, 2a, e) may have been triggered by build-up of excess pore-pressure due to rapid sedimentation or by oversteepening of the slope (e.g. Dowdeswell et al. 1996).

The dimensions and geometry of the linear to curvilinear depressions in Belcher Inlet (Fig. 1a), with widths of up to $50 \mathrm{~m}$ and small berms either side of a central depression, suggest that they are ploughmarks formed by iceberg keels grounding on the seafloor (e.g. Woodworth-Lynas et al. 1991). The relative absence of ploughmarks on the seafloor of Belcher Inlet (Fig. 2e) suggests that icebergs which are presently calved from the outlet glaciers of the Devon Ice Cap have keels which are usually shallower than around $100 \mathrm{~m}$. Given that ice thickness close to the terminus of Belcher Glacier has been measured at about $250 \mathrm{~m}$ using airborne radar methods (Fig. 1c), the majority of the icebergs are probably fragmenting upon calving.

\section{Discussion: a tidewater glacier landform assemblage in Belcher Inlet}

The glacigenic landforms preserved on the seafloor of Belcher Inlet (Fig. 2e) form assemblages that record the dynamic behaviour of Belcher Glacier and the unnamed glacier to the immediate north at two timescales: linked first to regional deglaciation after the Last Glacial Maximum (LGM) and, secondly, to more local Little Ice Age advance and subsequent retreat (Fig. 1a).

Seaward of the break in slope, subtle lineations and ice-sculpted bedrock provide evidence for the advance of fast-flowing grounded ice in a northeasterly direction through Belcher Inlet (Fig. 2e). This ice advance probably occurred during the LGM, when the Innuitian Ice Sheet inundated the islands of the Canadian Arctic and extended into Baffin Bay (England et al. 2006).

Three sediment wedges, interpreted as GZWs, show the position of ice-margin still-stands during overall retreat from the LGM (Fig. 2e). The presence of GZWs suggests that the ice in Belcher Inlet underwent rapid regional retreat during deglaciation, punctuated by relatively long (decades to centuries) still-stands (Dowdeswell et al. 2008). An ice shelf of unknown length was probably present at the glacier terminus, in order to restrict vertical accommodation space during GZW formation (Batchelor \& Dowdeswell 2015).

Landward of the break in slope in Belcher Inlet (Fig. 2e), we infer that the assemblage of submarine landforms is related to glacier advance and subsequent retreat linked to the cool Little Ice Age. Subglacially produced sedimentary lineations record the advance of fast-flowing, grounded ice in an easterly to northeasterly direction (Fig. 2e). Swarms of ice marginal De Geer moraines show the positions of short-lived still-stands of the grounding zone during subsequent slow retreat of grounded tidewater glacier margins (Fig. 2e). In this case, sedimentation was unconstrained by a floating ice shelf (conditions were not sufficiently cold for ice-shelf formation), allowing vertical ridge-building. The De Geer moraines immediately seaward of the unnamed glacier (Fig. 2a, c) were formed between the 1960s and 2006, whereas the De Geer moraines beyond Belcher Glacier (Fig. 1b) were formed prior to the 1960s (Fig. 1a).

Several iceberg ploughmarks and sediment lobes are also identified on the seafloor of Belcher Inlet (Fig. 2e). However, the landforms and sediments preserved in Belcher Inlet have not been subjected to significant reworking by iceberg keels or mass-movement events.

\section{References}

ALLEY, R. B., ANANDAKRISHNAN, S., DUPONT, T. K., PARIZEK, B. R. \& POLLARD, D. 2007. Effect of sedimentation on ice-sheet groundingline stability. Science, 315, 1838-1841.

BATCHELOR, C. L. \& DOWDESWELL, J. A. 2015. Ice-sheet groundingzone wedges (GZWs) on high-latitude continental margins. Marine Geology, 363, 65-92.

BENN, D. \& EVANS, D. J. A. 2010. Glaciers and glaciation. $2^{\text {nd }}$ Edition. Hodder Arnold Publication.

DOWDESWELL, J. A., KENYON, N., ELVERHØI, A., LABERG, J. S., MIENERT, J. \& SIEGERT, M. J. 1996. Large-scale sedimentation on the glacier influenced Polar North Atlantic margins: long-range side-scan sonar evidence. Geophysical Research Letters, 23, 3535-3538.

DOWDESWELL, J. A., OTTESEN, D., EVANS, J., Ó COFAIGH, C. \& ANDERSON, J. B. 2008. Submarine glacial landforms and rates of icestream collapse. Geology, 36, 819-822.

DOWDESWELL, J. A., BENHAM, T. J., GORMAN, M., BURGESS, D. \& SHARP, M. J. 2004. Form and flow of the Devon Island Ice Cap, Canadian Arctic. Journal of Geophysical Research, 109, F02002.

DOWDESWELL, J. A. \& FUGELLI, E. M. G. 2012. The seismic architecture and geometry of grounding-zone wedges formed at the marine margins of past ice sheets. Geological Society of America Bulletin, 124, 1750-1761.

ENGLAND, J., ATKINSON, N., BEDNARSKI, J., DYKE, A. S., HODGSON, D. A. \& Ó COFAIGH, C. 2006. The Innuitian Ice Sheet: configuration, dynamics and chronology. Quaternary Science Reviews, 25, 689-703.

LINDÉN, M. \& MÖLLER, P. 2005. Marginal formation of De Geer moraines and their implications to the dynamics of grounding-line recession. Journal of Quaternary Science, 20, 113-133.

SHIPP, S. \& ANDERSON, J. B. 1997. Grounding zone wedges on the Antarctic continental shelf, Ross Sea. In: Davies, T.A., Josenhans, H., Polyak, L., Solheim, A., Stoker, M.S., Stravers, J.A. (eds.), Glaciated Continental Margins: An Atlas of Acoustic Images. Chapman \& Hall, London, 104-105.

SOLHEIM, A. \& ELVERHØI, A. 1997. Submarine glacial flutes and De Geer moraines. In: Davies, T.A., Josenhans, H., Polyak, L., Solheim, A., Stoker, M.S., Stravers, J.A. (eds.), Glaciated Continental Margins: An Atlas of Acoustic Images. Chapman \& Hall, London, 104-105.

SOLHEIM, A., RUSSWURM, L., ELVERHØI, A. \& NYLAND BERG, M. 1990. Glacial geomorphic features in the northern Barents Sea: direct evidence for grounded ice and implications for the pattern of deglaciation and late glacial sedimentation. In: Dowdeswell, J.A. \& Scourse, J. D. (eds.), Glacimarine Environments: Processes and Sediments. Geological Society, London, Special Publications, 53, 253-268.

VAN WYCHEN, W., BURGESS, D. O. et al. 2014. Glacier velocities and dynamic ice discharge from the Queen Elizabeth Islands, Nunavut, Canada. Geophysical Research Letters, 41, 484-490.

WOODWORTH-LYNAS, C. M. T., JOSENHANS, H. W., BARRIE, J. V., LEWIS, C. F. M. \& PAROTT, D. R. 1991. The physical processes of seabed disturbance during iceberg grounding and scouring. Proceedings of the Canadian Continental Shelf Seabed Symposium, 11, 939-961. 

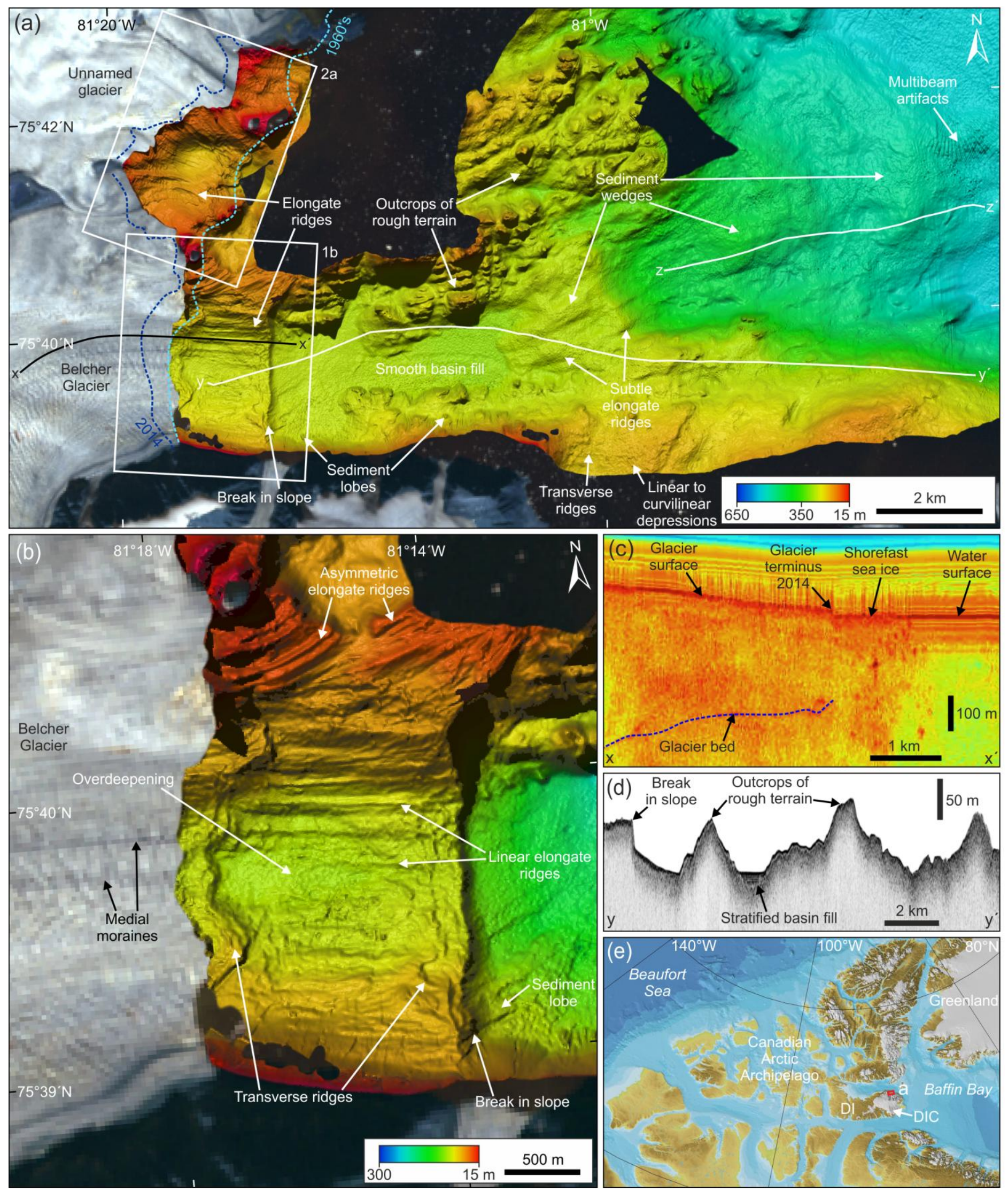

Figure 1. (a) Swath bathymetry of Belcher Inlet, Arctic Canada (2006), superimposed on 2000 Landsat 7 satellite imagery. Multibeam acquisition systems Kongsberg EM300 and Kongsberg EM3002S. Frequency $30 \mathrm{kHz}$ and $300 \mathrm{kHz}$, respectively. Grid-cell size $10 \mathrm{~m}$. Light blue and dark blue dashed lines are terminus positions derived from 1960s and 2014 aerial photos, respectively. (b) Multibeam bathymetric image of the seafloor immediately in front of Belcher Glacier. (c) 2014 airborne radar profile of Belcher Glacier, showing the depth of the glacier bed (blue dashed line). (d) Sub-bottom profile along Belcher Inlet, showing outcrops of rough terrain and acoustically stratified basin-fill sediments. Acquisition systems Knudsen 320R and Knudsen 320B. Frequency $3.5 \mathrm{kHz}$ chirp ( 2-8 kHz). VE x 30. Sub-bottom profile (d) is located in Fig. 1a. (e) Location of study area (red box; map from IBCAO v. 3.0). Devon Island (DI). Devon Ice Cap (DIC). 


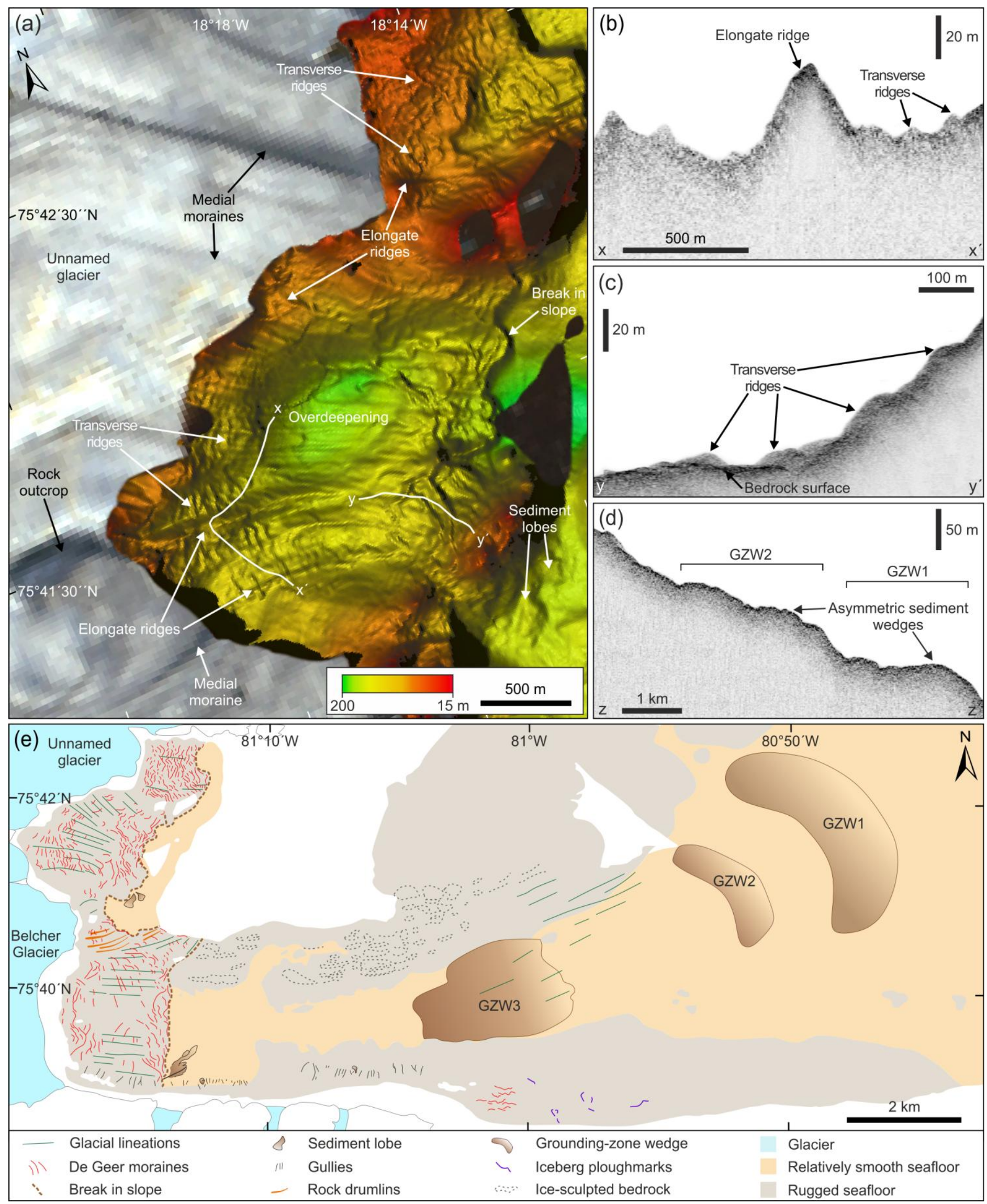

Figure 2. (a) Multibeam bathymetric image of the seafloor immediately in front of the unnamed glacier to the north of Belcher Glacier. (b) Sub-bottom profile across an elongate ridge on the seafloor in front of the unnamed glacier. VE x 8. (c) Sub-bottom profile across a series of transverse ridges on the seafloor in front of the unnamed glacier. VE x 4. Sub-bottom profiles (b) and (c) are located in Fig. 2a. (d) Sub-bottom profile through two sediment wedges in Belcher Inlet. VE x 14. Sub-bottom profile (d) is located in Fig. 1a. (e) Schematic diagram of the landforms identified in Belcher Inlet. 